\title{
Diversity of Dragonflies (Insecta: Odonata) in a Deciduous Forest of Thoothukudi District, Tamil Nadu, South India
}

\author{
Anita Kannagi ${ }^{1}$, V. Sivakumar ${ }^{2}$, V. Santhi ${ }^{1}$ \\ ${ }^{1}$ Research Centre of Zoology, Jayaraj Annapackiam College for Women (Autonomous), Periyakulam, Tamil Nadu, India \\ ${ }^{2}$ Department of Zoology, VOC College, Thoothukudi, Tamil Nadu, India \\ Email address: \\ Anitaarul1911@gmail.com (A. Kannagi),drsivak@gmail.com (V. Sivakumar), velu.santhi62@gmail.com (V. Santhi)
}

\section{To cite this article:}

Anita Kannagi, V. Sivakumar, V. Santhi. Diversity of Dragonflies (Insecta: Odonata) in a Deciduous Forest of Thoothukudi District, Tamil Nadu, South India. International Journal of Environmental Protection and Policy. Vol. 4, No. 3, 2016, pp. 58-63.

doi: $10.11648 /$ j.ijepp.20160403.13

Received: March 29, 2016; Accepted: May 11, 2016; Published: May 192016

\begin{abstract}
The study of Odonata communities along deciduous forest requires the basic understanding of the abundance, distribution and number of species present. As habitat conditions change, they also exhibit changes in their diversity and distribution. The present study was carried out in Kuthiraimozhi theri deciduous forest located in Thoothukudi District, Tamil $\mathrm{Nadu}$, South India during July 2009 to June 2010 to assess the diversity of odonates. The forest is open, sandy, low tree lands with predominance of thorny, usually hard wood species. Observations were carried out twice in a month during morning, and evening times. A total of 958 dragonflies belonging to 20 species ( 2 species unidentified) belonging to 16 genera and 4 families were recorded. The family Libellulidae (15 species) was found to be dominant in the study region, followed by families Aeshnidae, Chlorogomphidae and Gomphidae, which were represented by a single species. The data was analyzed for Species richness, Shannon's diversity index and Simpson's index. Maximum number (237) of dragonflies was collected during December 2009 and the highest Species richness (2.35) and Shannon's diversity index (2.08) was recorded during June 2010. This study has shown that, Odonata diversities along the Kuthiraimozhi theri deciduous forest vary hence these populations can be monitored, related and used as indicators of the physical structure of the deciduous forest and its surrounding ecotones. This inventory has served as the baseline for Odonata communities in the deciduous forest hence can be a measure of monitoring in the near future. Finally, there must be an increase in education on the importance of using local insect species as first level indicators of environmental health which when improved upon can save the nation a lot of money otherwise used in the chemical evaluation and monitoring of environment.
\end{abstract}

Keywords: Odonata, Diversity, Deciduous Forest

\section{Introduction}

The mighty land of India is not only famous for its culture, architecture, heritage, but also for its jungles, forest and wild life. Indian forests are the richest assemblage of biodiversity, which reflects underlying climatic, topographic, biogeography and biotic evolutionary diversity. The term forest implies 'natural vegetation' of the area, existing from thousands of years and supporting a variety of biodiversity forming a complex ecosystem, which predominantly composed of trees, shrubs and is usually a closed canopy. The forest cover of India is assessed as 67.83 million hectares which constitute $20.64 \%$ of the country's geographical area. In India, of the $86 \%$ of the tropical forest area, $54 \%$ is dry deciduous and rest is evergreen [1]. Tamil Nadu state is spread over a geographical area of $1,30,058$ sq. $\mathrm{km}$ and has a recorded forest area of 22,877 sq. $\mathrm{km}$ accounting for $17.59 \%$ of its total geographical area. Forest vegetation in South India essentially comprises tropical thorn forests which occupy a considerable area. The role of insects in the preservation of indispensable life support systems in natural habitats is well recognized.

The insect order Odonata includes some of the most ancient and beautiful insect that ever roamed earth [2]. Approximately 6000 species and subspecies to 630 genera in 28 families are known from all over the world [3], out of which 499 species and subspecies of Odonata under 139 genera in 17 families, 
are represented in India [4]. Odonate with 474 species in 142 genera and 18 families are known from India [5]. The presence of dragonflies is important indicators for ecological balance. Odonates were the first insect group that has been globally assessed [6]. Dragonflies have been extensively used as indicators of environmental quality in aquatic ecological units [7]. Dragonflies are key organisms of the food web as predators both as larvae and as imagoes [8]. Odonates play important ecological roles as both predators and prey, loss of odonata species could have a ripple effect (known in ecology as a trophic cascade) on terrestrial and aquatic food webs [9]. Dragonflies are very valuable insect and the knowledge of the fauna is important for decision making about environmental protection and crops management [10].

The odonate fauna of Kerala is well documented, some of the prominent works include $[11,12,13,14,15,16,17,18$, $19,20,21,22,23,24,25]$, which provided information regarding the status and distribution of odonates in different parts of Kerala. Total of 23 species belonging to 13 genera and 4 families were recorded from Sindhudurg district, Maharashtra, India [26]; total of 26 species of dragonflies (sub-order Anisoptera) belonging to 3 families were recorded from the Bodoland University between May 2013 to November 2014 [27]; 21 species of odonates were recorded from Coimbatore and Salem districts in Tamil Nadu [28]; 66 species of odonates from the state of Goa [29]; 13 more species of odonates from the state of Goa [30]; and 52 species of odonates from Kerala Agricultural University Campus, Thrissur, Kerala. [31].

But insufficient records are acknowledged about the diversity of odonates in the deciduous forest in Eastern Ghats. So the present work was undertaken to study diversity of odonates in a deciduous forest in South India from July 2009 to June 2010.

\section{Materials and Methods}

\subsection{Study Area}

The Kuthiraimozhi theri deciduous forest is located in between $8^{\circ} 32^{\prime} 25.01 " \mathrm{~N}$ latitudes and $78^{\circ} 2{ }^{\prime} 28.98^{\prime \prime} \mathrm{E}$ longitudes in Thoothukudi District, Tamil Nadu, South India. It comprises tropical thorn forests, which occupy a considerable area of about 1440 hectares. The forests are open, sandy, low tree lands with predominance of thorny, usually hard wood species. The genus Acacia and several other genera allied to Acacia is characteristic of the flora found in this area. Apart from this, spiny, low shrubs and few climbers are also present. A thin layer of grass grows during monsoon season and the soil is barer during the drier months.

The climate of South east coast of India is broadly described as tropical monsoon type with four seasons namely i) Post-monsoon season (Jan. - Mar.), ii) Summer (Apr. Jun.), iii) Pre-monsoon season (Jul. - Sep.) iv) and Monsoon season (Oct. - Dec.).

\subsection{Collection and Preservation of Specimen}

Sites were selected in the proposed deciduous forest and a random sampling was then conducted from July 2009 to 2010 . The odonates were normally collected by various direct collections.

Observations were carried out twice in a month during morning, and evening times. Species were photographed and identified in their natural habitat, but in few cases when it was difficult to assess, then specimens were captured for their further identification and after that they were released in their natural habitat. Collections of specimens were done with the help of specially designed insect net.

The aerial net was used for collecting flying insects especially the butterflies and the dragonflies. Aerial nets typically have net bags that are composed entirely of some type of meshed material and often have a light weight handle. For the present study the white aerial net bags were used for effective collection. Aerial nets with larger hoops were used for collecting large and fast moving insects such as butterflies and the dragonflies.

\subsection{Data Analysis}

The diversity indices viz. Shannon Weiner index (H'), Simpson's index $(\lambda)$, species richness (R1 and R2) were calculated by using GW-Basic version 3.22.

\subsubsection{Species Richness Index (SR)}

Species richness means equal distribution of individual belonging to different species.

Margalef index (R1)

Margalef index (R1) was calculated using the following formula,

$$
\mathrm{R} 1=\frac{\mathrm{S}-1}{\log \mathrm{N}}
$$

Key:

$\mathrm{S}=$ Total number of species in a community

$\mathrm{N}=$ Total number of individuals observed.

\subsubsection{Diversity Indices}

Shannon-Wiener index ( $\left.H^{\prime}\right)$

Diversity was calculated by using the following formula,

$$
\mathrm{H}^{\prime}=\frac{\mathrm{S}}{\sum s i=1\left[\left(\frac{N i}{N}\right) \operatorname{In}\left(\frac{N i}{N 1}\right)\right]}
$$

Key:

$\mathrm{Ni}=$ Number of individual species in the sample

$\mathrm{N}=$ Total number of individuals in the sample

In $=$ Number of individuals

Simpson's index $(\lambda)$

The measure equals the probability that two entities taken at random from the dataset of interest represent the same type. It equals: 


$$
\lambda=\sum_{i=1}^{R} \mathrm{P}^{n}
$$

$\lambda$ Obtains small values in data sets of high diversity and large values in data sets of low diversity.

\section{Results and Discussion}

In our study 20 species ( 2 unidentified) of odonates belonging of 4 families and 16 genera were recorded (Figure 1). Among them 15 species were from the family Libellulidae and only 1 species by the families Aeshnidae, Chlorogomphidae and Gomphidae were recorded (Table 1). The most diverse and abundant family is Lebellulidae and least diverse and abundant families are Aeshnidae, Chlorogomphidae and Gomphidae. Earlier studies on the Kerala odonates also have reported Libellulidae as the dominant odonate family $[17,26,27]$.

Table 1. Showing the month wise representation of individual species per hectare in the order Odonata in the Deciduous forest.

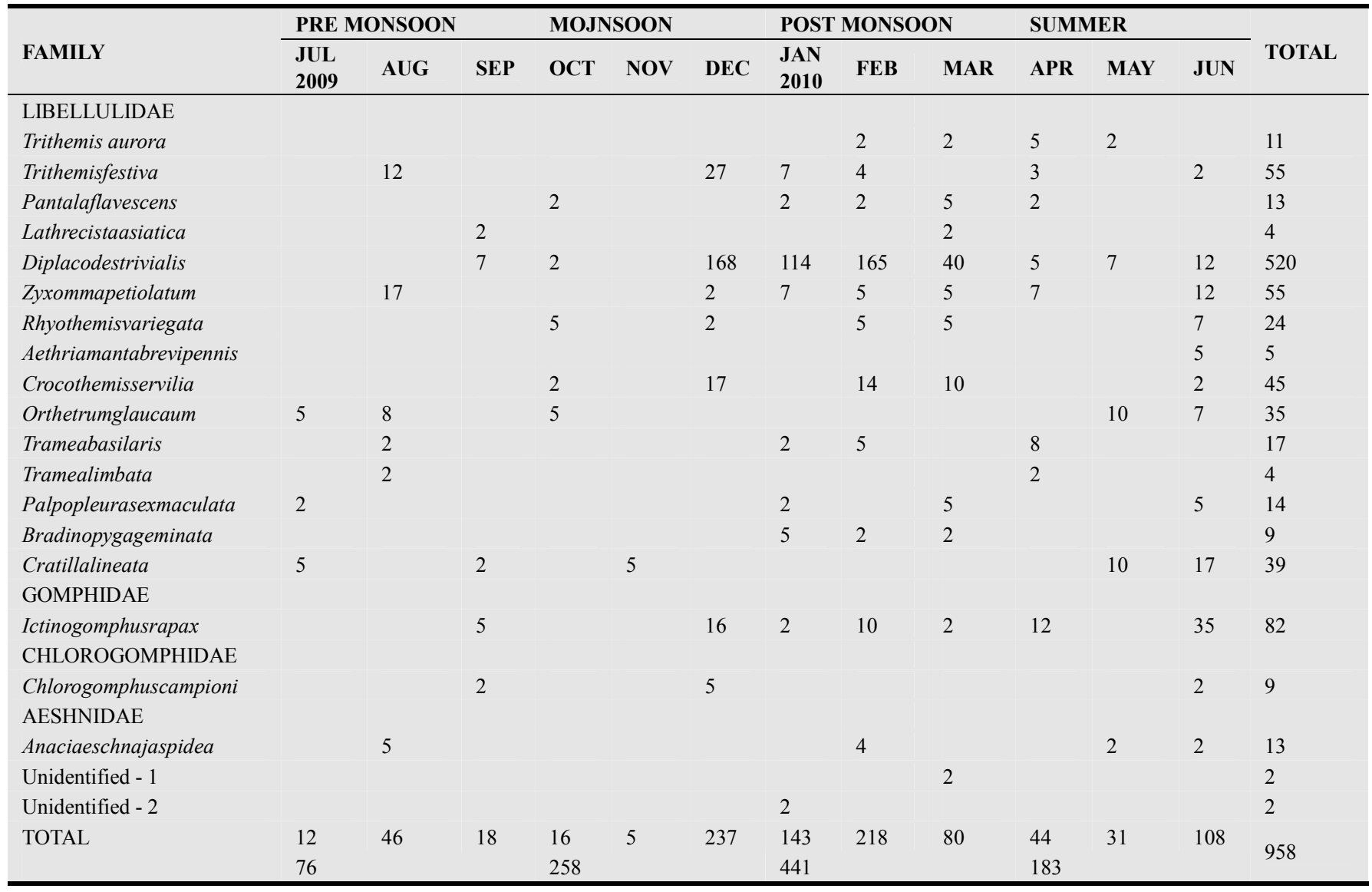

In the present study maximum number of species was recorded during the post-monsoon season, which might be due to the availability of prey population, which in turn depends on forest vegetation and the nearby agro ecosystem. From present study we conclude that the Family Lebellulidae is the most dominant family comprising $75 \%$ of species respectively and the most abundant species is Diplacodes trivialis in present study area.

The life history of odonates is closely linked with water bodies. They use a wide range of flowing and stagnant water bodies. They exhibit complex life histories requiring use of both aquatic habitat as larvae and littoral, riparian and upland areas as adults for maturation, foraging and mating.

In the monsoon season the tanks and ponds were almost filled with water which paves way for the breeding of dragon flies and the adults could have emerged in the post-monsoon season. Odonata also exhibited more abundance during post monsoon in the deciduous forest (Table 1). This might be due to favourable climatic conditions and also the presence of aquatic vegetation in the habitat. Further during postmonsoon season the availability of the prey of odonates were maximum due to rich vegetation in the forest area after heavy downpour. The abundance of prey in the post-monsoon season reflected the presence of many odonates in the habitat. Dragon flies preferred small flies (Diptera) to large flies. Similar findings were observed by $[25,32,33,34,35,36]$.

The availability of fresh water throughout the year in the post monsoon season in the deciduous forest, make the Odonata feel at home because it needs fresh water for its reproduction. Less number of Odonata was recorded during pre-monsoon season might be due to dry climate and lack of vegetation (Figure 2).

The richness indices (R1) were highest (2.35) in June indicating species richness of odonates was greatest during 
this period. The H' value (Shannon's diversity index) was higher (2.08) in June and Simpson's index $(\lambda)$ was minimum
(0.161) indicating high diversity in June 2010 (Table 2).

Table 2. Showing the diversity of the order Odonata in the Deciduous forest (per hectare).

\begin{tabular}{|c|c|c|c|c|c|c|c|c|c|c|c|c|}
\hline INDEX & JUL 2009 & AUG & SEP & OCT & NOV & DEC & JAN 2010 & FEB & MAR & APR & MAY & JUN \\
\hline NO & 3 & 5 & 5 & 5 & 1 & 7 & 9 & 11 & 11 & 7 & 5 & 12 \\
\hline $\mathrm{R} 1$ & 0.805 & 1.384 & 1.384 & 1.443 & 0 & 1.097 & 1.612 & 1.857 & 2.282 & 1.586 & 1.165 & 2.349 \\
\hline$\lambda$ & 0.318 & 0.222 & 0.222 & 0.192 & 1 & 0.524 & 0.640 & 0.658 & 0.275 & 0.165 & 0.243 & 0.161 \\
\hline $\mathrm{H}^{\prime}$ & 1.028 & 1.456 & 1.456 & 1.507 & 0 & 1.024 & 0.892 & 1.064 & 1.761 & 1.801 & 1.420 & 2.079 \\
\hline
\end{tabular}

R1 - Margalef index, $\lambda$ - Simpson's index, H' - Shannon-Wiener index.

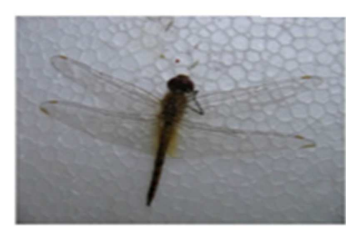

01. Trithemis aurora

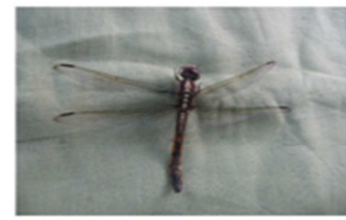

04. Lathrecista asiatica

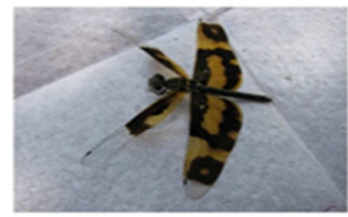

07. Rhyothemis variegata

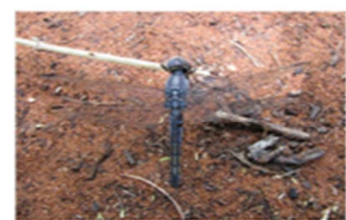

10. Orthetrum glaucaum

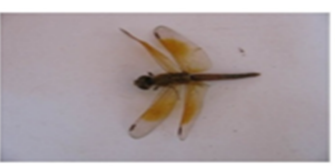

13. Palpopleura sexmaculata

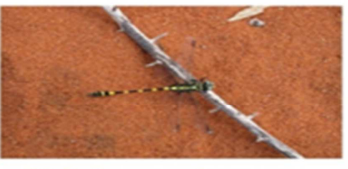

16. Ictinogomphus rapax

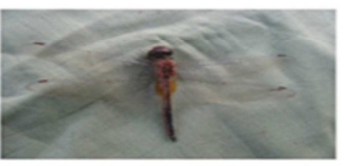

19. Unidentified - 1

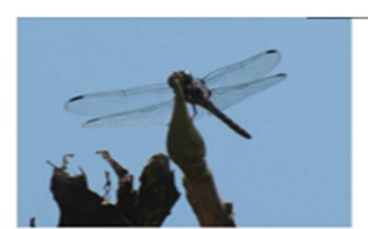

02. Trithemis festiva

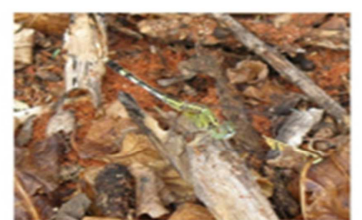

05. Diplocodes trivialis

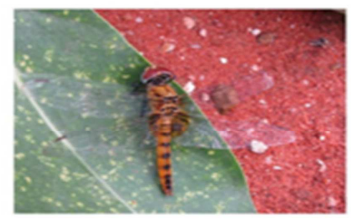

08. Aethriamanta brevipennis

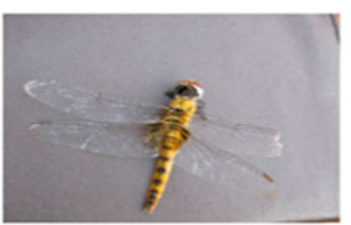

11. Tramea basilaris

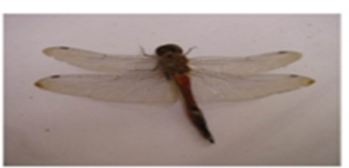

14. Bradinopyga geminata

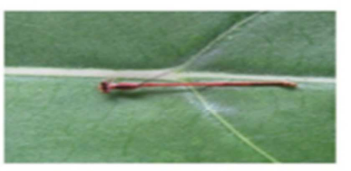

17. Chlorogomphus campioni

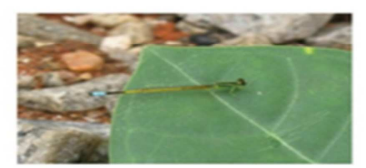

20. Unidentified - 2

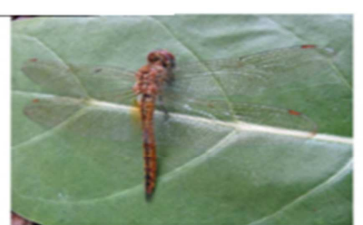

03. Pantala flavescens

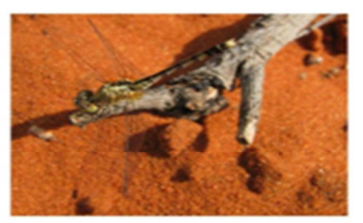

06. Zyxomma petiolatum

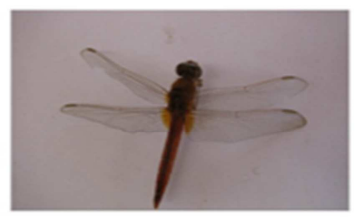

09. Crocothemis servilia

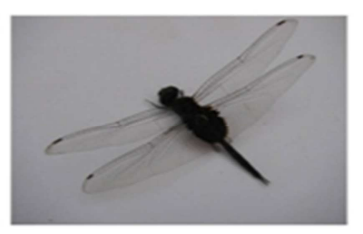

12. Tramea limbata

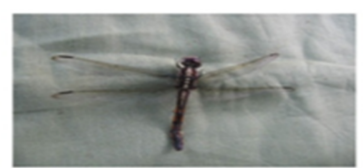

15. Cratilla lineata

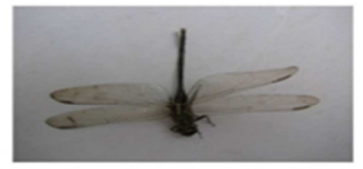

18. Anaciaeschna jaspidea

Figure 1. Showing the images of the dragonflies present in the study area during July 2009 to June 2010. 


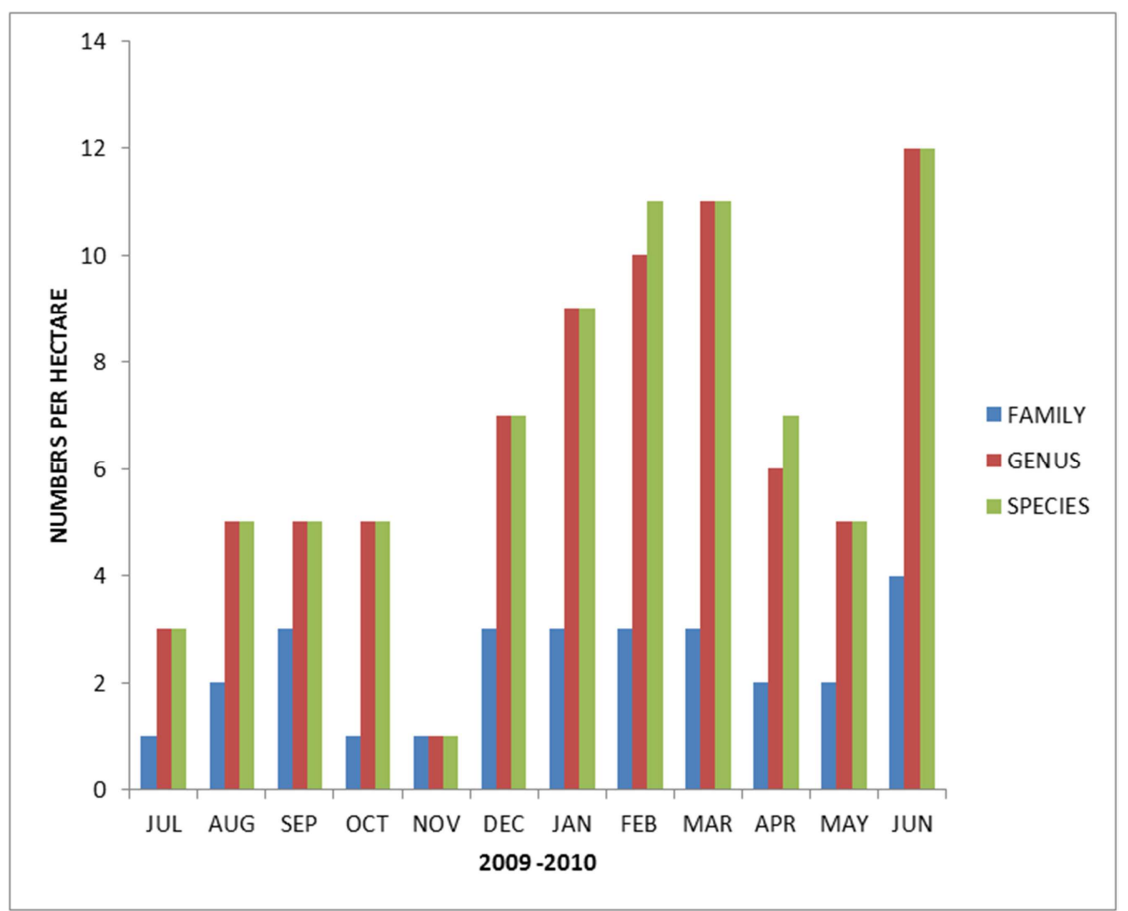

Figure 2. Month wise diversity of families, genus and species in the order Odonata in the Deciduous forest.

\section{Conclusion}

Destruction of tropical forest is doubtless the most important danger to global odonate diversity potentially resulting in the extinction of numerous species. Unfortunately these species are often feebly known, making it difficult to say whether a species is truly rare or simply ignored. Having specific ecological and biological needs, together with high species population, abundance and diversity, made odonates as one of the most important biological indicators used to monitor environmental changes.

\section{Acknowledgements}

The authors are grateful to the Jayaraj Annapackiam College, Periyakulam, and the Principal V. O. C. College. Thanks are due to Prof. V. Sivakumar for his unremitting encouragement and valuable suggestions and also acknowledge UGC, Hyderabad for their financial assistance.

\section{References}

[1] O. N. Kaul, and D. C. Sharma, Forest type Statistics. Indian Forester 1971, 97, pp. 432-436.

[2] G. Sharma, R. Sundararaj \& L. R. Karibasvaraja. Species diversity of Odonata in the selected provenances of Sandal in southern India. Zoo's Print Journal 2007, 22 (7), pp. 27652767; http://dx.doi.org/10.11609/ oTT.ZPJ.1593.2765-7.

[3] S. Tsuda. A distributional list of world Odonata. Osaka, 1991, pp. 362.

[4] M. Prasad, and R. K Varshney. Oriental Insects. 1995, 29, pp. $385-428$.
[5] K. A. Subramanian. A Checklist of Odonata of India. Zoological Surveyof India, Kolkata, 2014, pp. 31.

[6] V. V. J. Clausnitzer, Kalkman, V. J. and Wilson, K. 2009. Odonata enter the biodiversity crisis debate: The first global assessment of an insect group. Biological Conservation 142, pp. $1864-1869$.

[7] A. Chovanec, and J. Waringer. Ecological integrity of riverfloodplain systems-assessment by dragonfly surveys (Insecta: Odonata). Regulated Rivers: Research and Manag. 2001, 17, pp. 493-507.

[8] A. C. Benke. Dragonfly production and prey turnover. Ecology 1976, 57, pp. 915-927.

[9] Remsburg AJ and Turner MG. Aquatic and terrestrial drivers of dragonfly (Odonata) assemblages within and among north temperate lakes. Journal of the North American Benthological Society, 200928 (1), pp. 44-56.

[10] R. Rowe. Dragonflies: Behaviour and Ecology of Odonata. Australian J. Entomol. 2003, 42 (2), pp. 210-211.

[11] G. Peters. Trockenzeit-Libellenausdem Indischen Tiefand. Deutsch Entomologische Zeitschrift (N. F.) 1981, 28, pp. 93108.

[12] R. Rao, \& A. R. Lahiri. First records of Odonates (Arthropoda: Insecta) from the Silent Valley and New Amarambalam Reserved Forests. Journal of the Bombay Natural History Society 1982, 79 (3), pp. 557-562.

[13] M. Prasad. A note on the odonata from south India. Fraseria 1987, 12, pp. 50.

[14] S. Mathavan, \& P. L. Miller. A Collection of Dragonflies (Odonata) made in the Periyar National Park, Kerala, South India, in January 1988. International Odonatological Society, Bilthoven (Rapid communications (supplements), no. 10), 1989, pp. 10. 
[15] C. Radhakrishnan. Ecology and conservation status of Entomofauna of Malabar. Zoos' Print 1997, 11, pp. 2-5.

[16] K. G. Emiliyamma, \& C. Radhakrishnan. Odonata (Insecta) of Parambikulam Wildlife Sanctuary, Kerala, India. Records of Zoological Survey of India 2000, 98 (1) pp. 157-167.

[17] K. G. Emiliyamma, \& C. Radhakrishnan. Additions to the Odonata of (Insecta) of Thiruvananthapuram District, Kerala. Zoo's Print Journal, 2002, 17 (10) pp. 914-917; http://dx.doi.org/10.11609/JoTT. ZPJ.17.10.914-7.

[18] M. J. Palot, D. Cheruvat, K. G. Emiliyamma \& C. Radhakrishnan. Dragonfly Menace at the National Fish Seed Farm, Malampuzha, Kerala. Fishing Chimes, 2002, 22 (5) pp. 56-60.

[19] K. A. Subramanian, \& K. G. Sivaramakrishnan. Conservation of Odonate fauna in Western Ghats, 2002, pp. 11-22. In Sanjayan, K. P., V. Mahalingam \& M. C. Muralirangan (eds.). Vistas of Entomological Research for The New Millennium. G. S. Gill Research Institute, Chennai.

[20] C. Radhakrishnan, \& K. G. Emiliyamma. Odonata (Insecta) of Kerala: A systematic Database, 2003, pp. 1-27. In: Gupta, R. K. (ed.). Advancement in Insect Biodiversity, Jai NarainVyas University, Jodhpur

[21] K. G. Emiliyamma, C. Radhakrishnan \& M. J. Palot. Pictorial Handbook on Common Dragonflies and Damselflies of Kerala. Zoological Survey of India, 2005, pp. 67.

[22] K. A. Subramanian., India-A Lifescape, Dragonflies of India A Field Guide. VigyanPrasar, India Offset Press, New Delhi, 2005, pp. 118.

[23] K. A. Subramanian. Endemic odonates of the Western Ghats: Habitat distribution and Conservation, 2007, pp. 257-271. In: Tyagi, B. K. (ed.). Odonata-Biology of Dragonflies. Scientific Publishers, Jodhpur, India.

[24] C. G. Kiran, \& D. V. Raju. Checklist of Odonata of Kerala with their Malayalam names. Malabar Trogon 2011, 9 (3): 3135 .

[25] C. G. Kiran. \& D. V. Raju. Dragonflies and damselflies of Kerala (Keralathile Thumbikal). Tropical Institute of Ecological Sciences, 2013, pp. 156.

[26] D. L. Bharamal1, Y. J. Koli, D. S. Korgaonkar and G. P.
Bhawane. Odonata fauna of Sindhudurg district, Maharashtra, India. International journal of Current Microbiology and Applied Sciences 2014, 3, 9, pp. 98-104.

[27] Paris Basumatary, D. Adhikary, M. Daimary, N. Basumatary, A. Daimary, A preliminary study on the diversity of odonata in Bodoland University and its vicinity, Assam, India. International Journal of Scientific and Research Publications, $2015,5,6$.

[28] Arulprakash, R. \& K. Gunathilagaraj., Abundance and diversity of odonata in temporary water bodies of Coimbatore and Salem districts in Tamil Nadu. Journal of Threatened Taxa 2010, $2 \quad$ (8): $1099-1102$ http://dx.doi.org/10.11609/JoTT.o2035.1099-102.

[29] Rangnekar, P., M. Borkar \& O. Dharwadkar, Additions to the Odonata (Insecta) of Goa. Journal of Threatened Taxa 2010, 2 (4): 805-814; http://dx.doi.org/10.11609/JoTT.o2286.805-14.

[30] Rangnekar, P. \& R. Naik, Further additions to the Odonata (Insecta) fauna of Goa, India. Journal of Threatened Taxa 2014, $\quad 6 \quad$ (3): $\quad 5585-5589$; http://dx.doi.org/10.11609/jott.o3641.5585-9.

[31] Adarsh, C. K., K. S. Aneesh \& P. O. Nameer, A preliminary checklist of odonates in Kerala Agricultural University (KAU) campus, Thrissur district, Kerala, Southern India. Journal of Threatened Taxa 2014, 6 (8): 6127-6137; http://dx.doi.org/10.11609/JoTT.o3491.6 127-37.

[32] A. Rashed, Christopher D. Beatty, Mark R. Forbes and Thomas N. Sherratt., Prey selection by dragonflies in relation to prey size and wasp - like colours and patterns. Animal Behaviour, 2005, 70, pp. 1195-1202.

[33] G. Pritchard., The prey of adult dragonflies in North Alberta. Canadian Entomologist, 1964, 96, pp. 821-825.

[34] P. J. Mayhew., Food intake and adult behaviour in Calopteryxspendens and Erthrommanajas. J. Odonatol. 1994, 23 (2) pp. 115-124.

[35] R. W. Merrit, and K. W. Cummins., Aquatic insects of North America, $3^{\text {rd }}$ edition. Kendall / Hunt Publishing Company. 1996, pp. 112-123.

[36] P. S. Corpet, Biology of Odonata. Ann. Rev. Entomol. 1999, 25, pp. 189-217. 